\title{
Characterizing the Fall and Association between Functional Independence and Balance in the Elderly Following Proximal Femoral Surgery
}

\section{Marla Andréia Garcia de Avila', Silvia Cristina Mangini Bocchi ${ }^{2}$}

\section{Abstract}

Introduction: Falling in the elderly should be considered sentinel events in the life of an individual, potentially marking in the initiation of an important decline in his functional capacity, have a multicausal etiology and can be attributed to extrinsic factors and intrinsic factors.

Objective: To characterize sociodemographics and the diseases of the elderly who sustained a proximal femoral fracture, as a result of falls from a standing height, and to study the relationship between balance and functional independence of these elderly.

Method: This was a cross-sectional study conducted over a period of 12 months in a teaching hospital, with a sample of 89 elderly ( $\geq$ 60 years)

Results: The characteristics of the elderly patients which demonstrated significance with functional independence were: the presence of nervous system disease, and/or mental and behavioural disorders ( $p$ $=0.001)$, and balance $(p<0.001)$. Surgeries in the proximal femoral region occurred in females (67.3\%), elderly patients $\geq 80$ years of age (46.1\%), and $60.7 \%$ underwent osteosynthesis.

Conclusions: In relationship to functional independence, $23.6 \%$ of the elderly were classified as maximum dependence, $38.2 \%$ as minimum, and $38.2 \%$ as modified independence. The elderly gained balance significantly as they regained their functional independence, regardless of age, gender, and whether or not they presented with nervous system disease and/or mental and behavioural disorders.
1 RN, PhD, Assistant Professor at Botucatu Medical School, Universidade Estadual Paulista (Unesp).

2 RN, PhD, Associate Professor at Botucatu Medical School, Universidade Estadual Paulista (Unesp), Brazil.

\section{Contact information:}

Marla Andréia Garcia de Avila.

Address: Faculdade de Medicina de Botucatu. Av. Prof. Mário Rubens Guimarães Montenegro, s/n. Bairro: UNESP. Campus de Botucatu, 18618687, Botucatu, SP.

Tel: +55143880707 .

झmarla@fmb.unesp.br

Keywords

Aging; Elderly; Accidental Falls; Femoral Fractures. 


\section{Introduction}

The population aging implies increased risk for the development of biological, socioeconomic and psychosocial vulnerabilities, due to typical biological decline of senescence, which interacts with sociocultural processes, with cumulativing effects of poor conditions of education, income and health. Individual vulnerability includes biological, emotional, cognitive, attitudinal and concerning social relations, promising context to falls [1]. Falling in the elderly should be considered sentinel events in the life of an individual, potentially marking the initiation of an important decline in his functional capacity [2]. The consequences include: a loss of confidence with walking due to the fear of a new fall episode, in such a way that the elderly decrease their mobility; increase in dependence; injuries such as bruises, cuts and fractures, including proximal femoral fractures [1-4].

In the United States, approximately 250,000 proximal femoral fractures occur each year, with a cost of nine billion dollars [3]. Within Brazil, one percent of the hospitalized elderly with an osteoporotic fracture who were seen in the Sistema Único de Saúde (Unified Health System: SUS), between 2006 and 2008, presented with a proximal femoral fracture as the primary diagnosis [4]. That said, these proximal femoral fractures in the elderly present different rates of mortality that vary according to advanced age, masculine gender, higher number of comorbidities, and severity [5]. In Brazil, the mortality was 32\% and the chance of death from falling in the elderly is significantly higher for females, age group above 69 years and elderly people with white skin color, widowed or single [6]. Performing the surgical procedure as soon as possible may decrease hospital length of staying and mortality in these patients [6-7].

Fractures in the proximal femoral region have a multicausal etiology and can be attributed to extrinsic factors (related to the environment, the type of housing, monthly income, and cultural factors) and intrinsic factors (higher age range, decreased function in those systems that compose or control posture, diseases, cognitive and behavioural disorders, inability to maintain or recover balance, and non-performance of muscular strengthening activities) [8-10].

Balance is an automatic and unconscious process that enable the individual to resist gravitational destabilization and to move. Its maintenance depends on the integration of the vestibular system, the eyes and the proprioceptive system that enable static and dynamic balance. There is a relationship between balance and the ability to perform activities of daily living (ADLs) [11].

The treatment of choice for the majority of fractures is surgery, except in those cases in which the patient presents with comorbidities that pose an unacceptable risk for anaesthesia, the surgical procedure, as well. In the presence of any of these factors, the indication is for conservative treatment. The objective of surgical treatment is to prevent the progression of functional incapacity and to restore the function of the limb so that it is similar to the pre-fracture status [12]. That said, the elderly in the post-operative period remain unable to walk without supporting the operated limb, and their rehabilitation can be influenced by their clinical conditions, the success of the treatment and of the rehabilitation process.

The recovery of functional independence after proximal femoral fracture is associated with the absence of dementia; age $<80$ years, the ability to ambulate, and the capacity to complete ADLs and instrumental activities of daily living (IADLs) without assistance [14]. Functional recovery is the highest when there is a higher initial physiologic score (prefracture) $[13,15]$.

The study that evaluated the quality of life in the elderly one year after surgical treatment for transtrochanteric femoral fractures showed the following: ADLs that depended on the lower legs worsened significantly, all IADLs were significantly worsened 
in more than $50 \%$ of the patients, and more than half of those who had previously walked without supporting lost this ability [16].

Assessing the functional independence and balance of the elderly is essential in the rehabilitation process after femur surgery for their quality of life and prevention of further falling. Therefore, the hypothesis to be tested was: there is a relationship between functional independence and balance in the elderly following surgery for fractures in the proximal region of the femur.

In order to test this hypothesis, this study had as its objectives: to investigate the sociodemographic characteristics and the occurrence of falling in the elderly after proximal femoral fractures, and to relate balance and functional independence with these characteristics.

\section{Method}

It is a cross-sectional study using nonprobabilitysampling method. It was conducted in the Hospital das Clínicas de Botucatu (HCB), in the state of São Paulo, Brazil, a major public institution linked to the regional SUS. Two thousand exams, 600,000 consults, 20,000 hospitalizations and 9,000 surgeries occur annually, with approximately 200 in the surgical specialty of hips, of which 100 of these are in the elderly as a result of falls.

The study was performed from November of 2011 to October of 2012, in agreement with Resolution 196/96 [17] (CEP Protocol 3967/2011), and included elderly $\geq 60$ years, post-operative for proximal femoral surgery after falling of low energy, and who were in their second month of ambulation or had received medical authorization to walk, excluding those who did not walk prior to the fracture. It is noteworthy that for the surgeries of total or partial arthroplasty, the elderly began to walk with partial weight bearing, in the first week and total weight bearing after the first month. In cases of osteosynthesis (reduction and fixation), the par- tial weight bearing was initiated one month after surgery, until the elderly could walk with the total weight bearing.

The concept of falling utilized was: "to inadvertently come to stay on the ground or another lower level, excluding intentional position changes to lean on furniture, walls or other objects" [18-19].

The independent variables observed were: sociodemographic, clinics and falling characterization; and the dependents (sex, age, the presence of disease in the nervous system and mental disorder affected by according to the International Classification of Diseases (ICD-10) and a balance score (Berg Balance Scale); and the outcome variable: functional independence.

The Berg Balance Scale (BBS) is an instrument validated by Berg et al., [23] with a transcultural adaptation for its application in Brazil [24], it evaluates the function of dynamic and static balance of individuals and the risk for falling considering environmental influence on the function. There are 14 tasks similar to activities of daily living (to sit, stand, reach, turn around on one's own, look over one's shoulders, stand on one foot, and navigate stairs). Scores are attributed that vary from zero, for inability to perform activities without assistance, up to four, for the ability to perform tasks independently. This version presented high intra- and inter-observer reliability (Intraclass Correlation Coefficient: ICC - of 0.99 and 0.98 , respectively), proving its usefulness for assessment of balance in elderly [24].

The Functional Independence Measure (FIM) is a multidimensional, translated [21] and validated for Brazilian Portuguese [22], that has as its primary objective to evaluate in a quantitative way the burden of care demanded by a person to complete series of motor and cognitive tasks of daily living [21-22]. These activities are distributed in two large domains: the motor (self-care, sphincter control, mobility and locomotion), and the cognitive (communication and social cognition) and receives a scoring that ranges from one (total dependence) to seven (complete 
independence). Thus, the total score ranges from 18 (high dependence) to 126 (complete independence) [21-22]. The patient describes how each task is accomplished and the evaluator scores according to the protocol for application of the instrument.

Subjects for the study were identified in the operating room: elderly, who had surgery performed on the proximal femoral region due to a low energy fall. For inclusion of subjects in the study was. Subsequently, data collection was performed in the outpatient area, by one of the investigators, using a form developed for this research, which is administered to the elderly along with their caregivers. The surgical information was collected from the patient's medical record. The home visit was performed when patients missed their clinic appointment, or when additional research data were required. The data were entered into a spread sheet in the Excel program and statistical analysis was conducted in two steps. In the first, a relationship between the independent variables with functional independence was investigated with nonparametric tests of MannWhitney, Kruskal-Wallis, Spearman and Chi-square. In the second step, a linear regression model was used with normal response adjusted to explain the functional independence score as a function of sex, age of the elderly patient, as well as variables that were significantly related with functional independence in step one. Residue analysis and diagnostics did not reveal any inadequacy of the use of the regression model with normal response. After the regression model to reveal the relationship between the presence of nervous system disease and mental the behavioural disorders, and functional independence, a comparison between elderly with and without diseases of these systems were conducted in relationship to scores obtained on the subscales of the FIM using the Mann-Whitney test. All effects and relationships associated to values of $p<0.05$ were considered significant.

\section{Results}

Considering the inclusion and exclusion criteria, the sample was composed of 89 elderly individuals. The surgeries were predominantly performed in women $(67.4 \%)$, those $\geq 80$ years of age, and those who earned up to three times the minimum wage $(R \$ 2.172,00 \approx$ USD \$907.08). In relationship to their place of origin, $52.9 \%$ resided in the same city in which they had their surgery (Botucatu) and the group was predominantly single, widowed or separated (53.9\%). With regard to the level of dependence evaluated by the FIM, the elderly were classified as: $23.6 \%$ maximum and moderate dependence, $38.2 \%$ minimal dependence or supervision and encouragement, and $38.2 \%$ modified or complete independence, as seen in Table 1.

Table 1. Characterization of the elderly following proximal femoral surgery, according to sociodemographic characteristics, BMI, number of medications used, functional independence and balance. Brazil, 2014.

\begin{tabular}{|c|c|c|}
\hline Variable & $\mathbf{N}$ & $\%$ \\
\hline \multicolumn{3}{|l|}{ Sex } \\
\hline Feminine & 60 & 67.4 \\
\hline Masculine & 29 & 32.6 \\
\hline \multicolumn{3}{|l|}{ Age (years) } \\
\hline 60 to 69 & 18 & 20.2 \\
\hline 70 to 79 & 30 & 33.7 \\
\hline$\geq 80$ & 41 & 46.1 \\
\hline \multicolumn{3}{|l|}{ Civil status } \\
\hline Widows, separated and single & 48 & 53.9 \\
\hline Married and living with a partner & 41 & 46.1 \\
\hline \multicolumn{3}{|l|}{$\mathrm{BMI}$ of the elderly } \\
\hline Underweight $\left(\mathrm{BMI}<22 \mathrm{~kg} / \mathrm{m}^{2}\right.$ ) & 27 & 30.3 \\
\hline Normal (BMI 22 a 27 kg/m²) & 50 & 56.2 \\
\hline Overweight (BMI > 27 kg/m²) & 12 & 13.5 \\
\hline \multicolumn{3}{|l|}{ Number of medications in use } \\
\hline$\leq 3$ & 40 & 45.0 \\
\hline$\geq 4$ & 49 & 55.0 \\
\hline Years of study * & \multicolumn{2}{|c|}{$3(0-15)$} \\
\hline Number of people in the same home* & \multicolumn{2}{|c|}{$3(1-7)$} \\
\hline
\end{tabular}




\begin{tabular}{l|c|c|}
\multicolumn{1}{|c|}{ Variable } & N & $\%$ \\
\hline Family salary in minimum wage & \multicolumn{2}{c|}{} \\
\hline$\leq 3$ & 62 & 69.7 \\
\hline From 4 to 7 & 18 & 20.2 \\
\hline$\geq 8$ & 9 & 10.1 \\
\hline Functional Independence Measure (FIM) & & \\
\hline Maximum/Moderate Dependence & 21 & 23.6 \\
\hline Minimum Dependence/Supervision & 34 & 38.2 \\
\hline Modified/Complete Independence & 34 & 38.2 \\
\hline FIM Motor * & $69(16-91)$ \\
\hline FIM Cognitive * & $25(5-35)$ \\
\hline FIM Total * & $92(25-125)$ \\
\hline Balance Score * & $26(3-56)$ \\
\hline
\end{tabular}

* Descriptive Summary as median (minimum and maximum).

Regarding the location of falling, $71.9 \%$ of these occurred during the day, $75.3 \%$ of these occurred in the home of the elderly individual, with $25.6 \%$ in an external area, $24.3 \%$ in the bedroom, and $19.0 \%$ in the bathroom and kitchen. The predominant activities that the elderly performed included: getting up from the bed/chair/sofa/toilet (30.3\%), walking in the house or on the street (25.9\%) and household activities (16.9\%). With regard to what occurred on the occasion of the fall, 39.3\% were attributed to lack of balance when getting up from the bed, chair, sofa and also from the toilet, or performing activities such as hanging up laundry outside, stooping to care for animals and children; $16.9 \%$ tripped on objects or an uneven floor or street; $13.5 \%$ slipped on rugs or wet flooring. It is noteworthy that $28.1 \%$ of the patients who fell were unable to attribute the fall to any factor, and believed that the fracture had occurred before the event, as shown in Table 2.

Among all of the characteristics investigated, only the presence of a nervous system disease and/or mental and behavioural disorders, and the balance scale score, were significantly related with the functional independence scores, where functional independence was highest in patients without nervous system and mental diseases
Table 2. Characterization of the fall of the elderly following proximal femoral surgery, regarding the location, the activity that was performed, and the time of day the fall occurred. Brazil,2014.

\begin{tabular}{|c|c|c|}
\hline Variables & $\mathbf{n}$ & $\begin{array}{c}\text { Relative } \\
\%\end{array}$ \\
\hline \multicolumn{3}{|l|}{ Location of the fall } \\
\hline Home of the elderly & 67 & 75.2 \\
\hline Outside the home (street, club, store) & 15 & 16.9 \\
\hline Another home (parent, neighbour) & 7 & 7.9 \\
\hline \multicolumn{3}{|l|}{ Room of the fall $(\mathrm{N}=74)$} \\
\hline Outside area (backyard, balcony) & 19 & 25.6 \\
\hline Bedroom & 18 & 24.3 \\
\hline Bathroom & 14 & 19.0 \\
\hline Kitchen & 14 & 19.0 \\
\hline Living room & 05 & 6.7 \\
\hline Did not know & 04 & 5.4 \\
\hline \multicolumn{3}{|l|}{ Activity being performed } \\
\hline Getting up from bed/chair/sofa/toilet & 27 & 30.3 \\
\hline Walking & 23 & 25.9 \\
\hline Household activities & 15 & 16.9 \\
\hline Going up/down stairs & 8 & 9.0 \\
\hline Taking a bath & 5 & 5.6 \\
\hline Physical activity & 2 & 2.2 \\
\hline Other and did not report & 9 & 10.1 \\
\hline \multicolumn{3}{|l|}{ Cause that led to the fall } \\
\hline Lack of balance & 35 & 39.3 \\
\hline Tripped & 15 & 16.9 \\
\hline Slipped & 12 & 13.5 \\
\hline Did not attribute a cause & 25 & 28.1 \\
\hline Did not remember & 2 & 2.2 \\
\hline \multicolumn{3}{|l|}{ Time of the fall } \\
\hline Day & 64 & 71.9 \\
\hline Night & 25 & 28.1 \\
\hline
\end{tabular}

$(p=0.001)$ and, also, in those elderly with higher balance scores $(p<0.001)$. Therefore, recognizing the influence of the nervous system and mental disorders on the functional independence scores, Table 3 shows the significant relationship in the self-care domains $(p=0.009)$, mobility/transferring 
$(p=0.017)$, communication $(p<0.001)$ and social cognition $(p<0.001)$.

Table 3. Comparison between elderly with and without nervous system disorder and/or mental and behavioural disorders, in relationship to the FIM domains.

\begin{tabular}{|c|c|c|c|c|}
\hline General & $\begin{array}{c}\text { FIM } \\
(n=89)\end{array}$ & $\begin{array}{l}\text { No disease } \\
\text { in the } \\
\text { Nervous } \\
\text { \& Mental } \\
\text { System } \\
(n=60)\end{array}$ & $\begin{array}{l}\text { Disease } \\
\text { in the } \\
\text { Nervous } \\
\text { \& Mental } \\
\text { System } \\
(n=29)\end{array}$ & $p^{1}$ \\
\hline Self-care & $\begin{array}{c}33 \\
(9-42)\end{array}$ & $\begin{array}{c}36 \\
(9-42)\end{array}$ & $\begin{array}{c}26 \\
(10-42)\end{array}$ & 0.009 \\
\hline $\begin{array}{l}\text { Sphincter } \\
\text { control }\end{array}$ & $\begin{array}{c}12 \\
(2-14)\end{array}$ & $\begin{array}{c}14 \\
(2-14)\end{array}$ & 12 & 0.220 \\
\hline $\begin{array}{l}\text { Mobility/ } \\
\text { Transfers }\end{array}$ & $\begin{array}{c}15 \\
(3-21)\end{array}$ & $\begin{array}{c}16 \\
(3-21)\end{array}$ & 12 & 0.017 \\
\hline Locomotion & $\begin{array}{c}6 \\
(2-14)\end{array}$ & $\begin{array}{c}7 \\
(2-14)\end{array}$ & $\begin{array}{c}5 \\
(2-14)\end{array}$ & 0.176 \\
\hline Communication & $\begin{array}{c}10 \\
(2-14)\end{array}$ & $\begin{array}{c}12 \\
(6-14)\end{array}$ & $\begin{array}{c}8 \\
(2-14)\end{array}$ & $<0.001$ \\
\hline Social Cognitive & $\begin{array}{c}15 \\
(3-21)\end{array}$ & $\begin{array}{c}16 \\
(8-21)\end{array}$ & $\begin{array}{c}9 \\
(3-19)\end{array}$ & $<0.001$ \\
\hline FIM Motor & $\begin{array}{c}69 \\
(16-91)\end{array}$ & $\begin{array}{c}74 \\
(16-91)\end{array}$ & $\begin{array}{c}49 \\
(19-91)\end{array}$ & 0.023 \\
\hline FIM Cognitive & $\begin{array}{c}25 \\
(5-35)\end{array}$ & $\begin{array}{c}28.5 \\
(14-35)\end{array}$ & $\begin{array}{c}18 \\
(5-33)\end{array}$ & $<0.001$ \\
\hline FIM Total & $\begin{array}{c}92 \\
(25-125)\end{array}$ & $\begin{array}{c}100.5 \\
(41-125)\end{array}$ & $\begin{array}{c}66 \\
(25-117)\end{array}$ & 0.001 \\
\hline \multicolumn{5}{|c|}{ Level of dependence } \\
\hline $\begin{array}{l}\text { Maximum } \\
\text { dependence }\end{array}$ & $\begin{array}{c}21 \\
(23.6 \%)\end{array}$ & $\begin{array}{c}11 \\
(18.3 \%)\end{array}$ & $\begin{array}{c}10 \\
(34.5 \%)\end{array}$ & \\
\hline $\begin{array}{l}\text { Minimum } \\
\text { dependence }\end{array}$ & $\begin{array}{c}34 \\
(38.2 \%)\end{array}$ & $\begin{array}{c}20 \\
(33.3 \%)\end{array}$ & $\begin{array}{c}14 \\
(48.3 \%)\end{array}$ & $0.082^{2}$ \\
\hline $\begin{array}{l}\text { Modified } \\
\text { independence }\end{array}$ & $\begin{array}{c}34 \\
(38.2 \%)\end{array}$ & $\begin{array}{c}29 \\
(48.3 \%)\end{array}$ & $\begin{array}{c}5 \\
(17.2 \%)\end{array}$ & \\
\hline \multicolumn{5}{|c|}{ 1: Mann-Whitney, 2 : Chi-square } \\
\hline
\end{tabular}

Table 4 presents the linear regression model adjusted to explain the independence in function of the presence of disease in the nervous system and mental disorder and in the balance score function.

According to the fit of the model, for every onepoint increase in the balance score, the degree of dependence increased significantly, on average 1.4
Table 4. Adjusted linear regression model to explain the level of functional dependence.

\begin{tabular}{|c|c|c|c|c|}
\hline Variables & $\beta$ & ep & $p$ & CI $(\beta ; 95 \%)$ \\
\hline Intercept & 44.1 & 16.6 & 0.009 & $(11.2-77.0)$ \\
\hline Masculine gender & -2.3 & 3.5 & 0.512 & $(-9.2-4.6)$ \\
\hline Age of the elderly & 0.1 & 0.2 & 0.778 & $(-0.3-0.4)$ \\
\hline Balance Scale & 1.4 & 0.1 & $<0.001$ & $(1.2-1.6)$ \\
\hline $\begin{array}{l}\text { Presence of nervous } \\
\text { system disease } \\
\text { Adjusted } \mathrm{R}^{2}=70.2 \%\end{array}$ & -7.5 & 3.5 & 0.038 & $(-14.5--0.4)$ \\
\hline
\end{tabular}

points, whereas elderly patients with nervous system disease and mental disorders showed an average reduction of 7.5 points in the dependence scores in relationship to the elderly free of these diseases. Sex and age, according to the model, were not significantly related with the degree of dependence, although male patients presented 2.3 fewer points on the FIM scores when compared to female patients.

\section{Discussion}

The occurrence of falls followed by proximal femoral fracture occurred predominantly in women (67.4\%), corroborating national [25-27] and international [5, 28] studies. Research conducted in 131 public hospitals in Spain that included 56,500 patients $\geq 60$ years, hospitalized for proximal femoral fractures, during the period 2002-2005, showed that 78.5\% of the fractures occurred in women [5], rates higher than those found in this study (67.4\%). In this study, the mean age was 79 years, with a range of 62-94 years. There was a predominance of elderly aged $\geq 80$ years $(46.1 \%)$, figures approaching that of the Americans, which revealed that the peak of proximal femoral fractures was in the age range of 85 years. It was also found that, between the ages of 60-85 years, the risk of fracture doubled for each 5-6 years of life [28]. It is emphasized that it is in the age group $\geq 80$ years in which there also exists 
a greater chance of the elderly dying [4], indicating the need to work even harder to prevent fractures and on the recovery of functional independence in this group of patients.

Regarding the investigation of marital status, in this study, the predominant group was single, widowed or separated (53.9\%). The literature indicates that unmarried individuals were more likely to fall when living alone [9, 25].

The most frequent location of falling was the home of the elderly individual, which is suggested as the first place to work with regard to prevention. It is the place where the elderly person spends the major part of the time exposed, many times, to architectural barriers of the house. The national study revealed that falling presented inadequate environment as a cause [27]. Other research also points to the homes of the elderly as the most likely location for a fall; many times, the house presents environmental inadequacies that favours falling [26].

Health professionals should be trained and sensitized to the issue, prepared in the assessment of these individuals and implementing interventions, with special attention to health promotion and popular education. [25-27]. Many difficulties arise both in the routine of the elderly individuals and their caregivers (hygiene, nutrition, comfort, dressings, consultations and medication use) as well as in the home (wheelchair, bathroom, hospital bed and physical structure) [25].

A national study that sought to correlate balance and the home environment with the risk for falls using the Adapted Environmental Risk for Falls Scale, in 25 elderly affected by cerebrovascular accident, revealed that $56 \%$ of households had scores above 20, showing high risk for falls for these elderly. The areas of locomotion, lighting, bedroom, bathroom and stairs presented risks to more than $50 \%$ of the study population [29].

The elderly who are postoperative for proximal femoral fracture have a temporary compromise of their functional independence. A study conducted in four hospitals in New York, including 532 patients aged 50 years or older, who were treated with surgery after proximal femoral fracture, found benefits of early ambulation in postoperative hip fracture. The authors believed that this could be achieved by stabilizing the patient and performing early surgery [30]. A national study that evaluated 70 patients who underwent partial hip arthroplasty found worsening of walking capacity in 33\% of cases [31]. The walking capacity in elderly having operations due to femoral fracture was the object of study, which showed worsening after a year of surgery. In addition, 43 patients (82.7\%) did not require assistance with ambulation before fracture and post-fracture, 23 (44.2\%) maintained their ability to ambulate without assistance. Six (11.5\%) patients did not recover their ability to walk after the fracture [16].

Regarding functional independence, in this study, no patient was considered to be in a state of total dependence, possibly because the study excluded elderly who were not walking prior to the fracture and those who did not receive authorization to begin the process of walking. They were classified as maximum or moderate dependence: $23.6 \%$ of the elderly, $38.2 \%$ with minimal dependence or supervision, and $38.2 \%$ with modified or complete independence. It was observed that functional independence was not significantly associated with age and sex.

A Brazilian study, showed that the fall caused a decrease in functional capacity of the elderly, both in functional independence and for IADLs, and that the older the elderly individual was, the greater the compromise in relation to his ability to perform his routine activities [15]. A study that evaluated the functional independence of elderly with fracture, on admission, at discharge, and after one month at home, observed considerable increase in mean values of the FIM motor and FIM total at the time of discharge compared to admission, however, when comparing the values achieved at 
home, there was a decrease in the mean values of the total FIM, according to the values investigated at the time of discharge [32]. The maintenance of functional capacity of the elderly is directly related to their ability to engage in enjoyable activities, even in very advanced age, prolonging, as long as possible, their autonomy and independence [15].

In this research, diseases of the neurological system and mental and behavioural disorders significantly correlated with the scores of the FIM. It is known that these diseases cause the reduction of physical capacity that may cause effects on postural control of the individual in general, effecting the dynamic equilibrium, and therefore end up being a risk factor for falls $[29,4]$. A comparison of the scores of the FIM of the elderly with and without disease in these systems was also significant in the fields self-care, mobility/transfer, communication and social cognitive. This study verified that older people with diseases in such systems also present lower balance scores and this was associated statistically with the scores of functional independence, which certainly shows how this population is vulnerable to falls and their consequences, and requires direct care from their caregivers.

Finally, it is believed that not knowing the prefracture conditions constituted a limitation of this study, however this leads to the same alert for the need to operationalize social policy and public health in the prevention of falls. Considering that $39 \%$ of the elderly attributed the rate of fall to a lack of balance, and that functional independence increased significantly as balance increased in the elderly who were postoperative proximal femur surgery, the incorporation of balance scales in clinical evaluation in medical, nursing and physical therapy protocols for the elderly is recommended.

\section{Conclusions}

The proximal femoral fractures occurred $67.4 \%$ in the female gender, $46.1 \%$ in elderly patients with $\geq 80$ years, and in $57.3 \%$ of the elderly who had osteosynthesis surgery. The falls occurred primarily in home of the elderly (75.2\%), in the external area $(25.6 \%)$, due to the lack of balance of the elderly (39.3\%) in getting out of the bed, chair, sofa or toilet (30.3\%). In the postoperative period, $23.6 \%$ of the elderly were classified as having maximum or moderate dependence, $38.2 \%$ with minimal dependence or supervision, and $38.2 \%$ modified or complete independence. Functional independence increases significantly to measure that the balance increases considering diseases in the nervous system and mental the behavioural disorders, age and sex of the elderly. Patients with nervous system diseases and mental the behavioural disorders had lower FIM scores when compared to those without diseases in these systems.

Beyond the tested and corroborated hypothesis, this study presents a contribution to future research when it shows the significant relationship for the domains of communication and social cognition, self-care and mobility/transfer as determinants of the dependency of the elderly with diseases of the nervous system and mental the behavioural disorders.

\section{Acknowledgements}

Fundação de Amparo à Pesquisa do Estado de São Paulo (Foundation for Research Support of the State of São Paulo: FAPESP)

\section{Declaration of interest}

The authors report no declaration of interest. Grant supporter, Fundação de Amparo à Pesquisa do Estado de São Paulo (Foundation for Research Support of the State of São Paulo: FAPESP), Process No. 2012/09618-4. 


\section{References}

1. Rodrigues NO, Neri AL. Social, individual and programmatic vulnerability among the elderly in the community: data from the FIBRA Study conducted in Campinas, Sao Paulo, Brazil. Cien Saude Colet. 2012; 17(8):2129-39.

2. Santos SSC, Silva ME, Pinho LB, Gautério DP, Pelzer MT, Silveira RS. Risk of falls in the elderly: an integrative review based on the North American Nursing. Rev esc enferm USP. 2012; 46(5):122736.

3. Bhandari M, Devereaux PJ, Tornetta P 3rd, Swiontkowski MF, Berry DJ, Haidukewych G, et al. Operative management of displaced femoral neck fractures in elderly patients. An international survey. J Bone Joint Surg Am. 2005; 87(9):2122-30.

4. Bortolon PC, Andrade CLT, Andrade CAF. O perfil das internações do SUS para fratura osteoporótica de fêmur em idosos no Brasil: uma descrição do triênio 2006-2008. Cad Saúde Pública. 2011; 27(4): 733-42.

5. Librero J, Peiró S, Leutscher E, Merlo J, Bernal-Delgado E, Ridao $M$, et al. Timing of surgery for hip fracture and in-hospital mortality: a retrospective population-based cohort study in the Spanish National Health System. BMC Health Serv Res. 2012; 12:15.

6. Rosa TSM, Moraes AB de, Peripolli A, Santos Filha VAV dos. Perfil epidemiológico de idosos que foram a óbito por queda no Rio Grande do Sul. Rev bras geriatr gerontol. 2015; 18 (1): 5969.

7. Bliemel C, Sielski R, Doering B, Dodel R, Balzer-Geldsetzer $M$, Ruchholtz S, Buecking B. Pre-fracture quality of life predicts 1-year survival in elderly patients with hip fracture-development of a new scoring system. Osteoporos Int. 2016; 27:1979-87.

8. Almeida ST, Soldera CLC, Carli GA, Gomes I, Resende TL. Análise de fatores extrínsecos e intrínsecos que predispõem a quedas em idosos. Rev Assoc Med Bras. 2012; 58(4):427-33.

9. Rocha SA, Avila MAG, Bocchi SCM. The influence of informal caregivers on the rehabilitation of the elderly in the postoperative period of proximal femoral fracture. Rev Gaúcha Enferm. 2016; 37(1):e51069.

10. Nogueira IMLMF et al. Falls Frequency In Elderly Assisted In The Family Health Strategy. International Archives of Medicine, [S.I.], v. 9, july 2016. ISSN 1755-7682. Available at: http://imed.pub/ ojs/index.php/iam/article/view/1610. Date accessed: 13 oct. 2016. doi: http://dx.doi.org/10.3823/1984

11. Prata MG, Scheicher ME. Correlation between balance and the level of functional independence among elderly people. Sao Paulo Med. J. 2012; 130(2):97-101.

12. Rocha MA, Azer HW, Nascimento VG. Evolução funcional nas fraturas da extremidade proximal do fêmur. Acta Ortop Bras. 2009; 17(1):17-21
13. Peetersa CMM, Visserb $E$, Van de Reea CLP, Gosensa $T$, Den Oudstend BL, Vriesb J. Quality of life after hip fracture in the elderly: A systematic literature review. Injury; 47(7): 1369-82.

14. Penrod JD, Litke A, Hawkes WG, Mgaziner J, Doucette JT, Koval $\mathrm{KJ}$, et al. The association of race, gender, and comorbidity with mortality and function after hip fracture. J Gerontol. 2008; 63(8):867-72

15. Fhon JRS, Fabrício-Wehbe SCC, Vendruscolo TRP, Stackfleth R, Marques S, Rodrigues RAP. Quedas em idosos e sua relação com a capacidade funcional. Rev Latino-Am Enferm. 2012; 20(5):927-34.

16. Guimaraes FAM, Lima RR, Souza AC, Livani B, Balangero WD. Avaliação da qualidade de vida em pacientes idosos um ano após o tratamento cirúrgico de fraturas transtrocanterianas do fêmur. Rev. Bras. Ortop.2011; 46 suppl1; 48-54.

17. Conselho Nacional de Saúde. Resolução 466/12. Diretrizes e normas regulamentadoras de pesquisa envolvendo seres humanos. Brasília: Ministério da Saúde; 2012.

18. São Paulo. Secretaria de Estado de São Paulo. Relatório global da OMS sobre prevenção de quedas na velhice. Tradução Letícia Maria de Campos. São Paulo: Centro de Produção e Divulgação Científica; 2010.

19. Falsarella GR, Gasparotto LPR, Coimbra AMV. Quedas: conceitos, frequências e aplicações à assistência ao idoso. Revisão da literatura. Rev bras geriatr gerontol. 2014; 17(4): 897-910.

20. Lipschitz DA. Screening for nutritional status in the elderly. Prim Care 1994; 21:55.

21. Riberto $M$, Miyazaki MH, Filho DJ, Sacamoto $H$, Battistella LR. Reprodutibilidade da versão brasileira da Medida de independência funcional. Acta Fisiatr. 2001; 8(1)45-52.

22. Riberto M, Miyasaki HM, Jucá SHH, Sakamoto H, Pinto PPN, Battistella LR. Validação da versão brasileira da Medida de Independência Funcional. Acta Fisiátrica 2004; 11:72-6.

23. Berg KO, Maki B, Williams JI, Holliday PJ, Wood-Dauphinee SL. Clinical and laboratory measures of postural balance in an elderly population. Arch Phys Med Rehabil 1992 Nov; 73 (11):1073-80.

24. Myamoto ST, Lombard Jr I, Berg KO, Ramos LR, Natour J. Brazilian version of the Berg balance scale. Braz J Med Biol Res. 2004; 37(9):1411-21.

25. Avila MAG, Pereira GJC, Bocchi SCM. Family participation to elderly rehabilitation with femoral fracture. Rev Bras Enferm. 2015; 68(5):883-9. 
26. Cruz DT, Ribeiro LC, Vieira MT, Teixeira MTB, Bastos RR, Leite ICG. Prevalência de quedas e fatores associados em idosos. Rev Saúde Pública. 2012; 46(1):138-46.

27. Soares DS, Mello LM, Silva AS, Nunes AA. Análise dos fatores associados a quedas com fratura de fêmur em idosos: um estudo caso-controle. Rev Bras Geriatr Gerontol. 2015; 18(2):239-48.

28. Kim SH, Meehan JP, Blumenfeld T, Szabo RM. Hip Fractures in the United States: 2008 Nationwide Emergency Department Sample. Arthritis Care Res. 2012; 64(5)751-7.

29. Santos BP, Nunes EMF, Henrique MMC. Correlação entre equilíbrio e ambiente domiciliar com risco de quedas em idosos com acidente vascular encefálico. Rev Bras Geriatr Gerontol. 2010; 13(1):41-50.

30. Siu AL, Penrod JD, Boockvar KS, Straus E, Morrison RS. Early ambulation after hip fracture: effects on function and mortality. Arch Intern Med. 2006; 166(7):766-71.

31. Ono NK, Lima GDA, Honda EK, Polesello GC, Guimarães RP, Ricioli JW, et al. Artroplastia parcial no tratamento da fraturas do Colo do fêmur. Rev Bras Ortop. 2010; 45(4):382-8.

32. Monteiro CRF, Mancussi C. Avaliação funcional de idoso vitima de fraturas na hospitalização e no Domicilio. Rev Esc de Enferm da USP. 2010; 44 (3): 719-4.

Publish in International Archives of Medicine

International Archives of Medicine is an open access journal publishing articles encompassing all aspects of medical science and clinical practice. IAM is considered a megajournal with independent sections on all areas of medicine. IAM is a really international journal with authors and board members from all around the world. The journal is widely indexed and classified Q2 in category Medicine. 